\title{
Sensory characteristic of new formulated Bir Pletok ice cream
}

\section{Dimas Bayu Pinandoyo ${ }^{1}$, Asriadi Masnar ${ }^{1}$, Ratih Titik Haryati ${ }^{2}$ and Sachin Badgujar ${ }^{3 *}$}

${ }^{1}$ Teknik Kemasan Politeknik Negeri Media Kreatif, Indonesia

${ }^{2}$ Seni Kuliner Politeknik Negeri Media Kreatif, Indonesia

${ }^{3}$ Department of Quality Control Kendriya Bhandar, India

\begin{abstract}
Bir Pletok is one of traditional heritage of Betawi Culinary. Till day, Bir Pletok's popularity is decreasing especially in young generation. This research aimed to get a new option of Bir Pletok product so that the acceptability and popularity of Bir Pletok as one of Betawi traditional culinary heritage can be preserved. Ice cream was made using mixing and freezing method. The composition for formulation was 3:1 for milk: Bir Pletok. Sensory characteristic measured with 7 levels hedonic methods. Triangle test was conducted to standardized the panelist. Panelist subjected for sensory test was semi trained panelist. Research was conducted in Politeknik Negeri Media Kreatif Art Culinary Department. Research found that overall acceptability of ice cream still medium (4.96). Respondents tend to slightly like the taste of Bir Pletok ice cream (5.47) neutrally respond to the aroma (4.67) and color (4.07), and tend to like the mouthfeel (5.53) and slightly like the after taste (5.07) of the ice cream.
\end{abstract}

\section{Article History}

Received March 3, 2021

Accepted June 29, 2021

\section{Keyword}

Bir Pletok, Sensory, Ice Cream, Formulation.

\section{Introduction}

Bir Pletok has been known as one of Betawi's culinary heritage. Bir Pletok created as an traditional drink made from endemic herb and spices to give reddish color and warm sensation to its consumers. Unfortunately, consumers these days tend to left Bir Pletok behind because "Bir" was identical with alcoholic beverages which less popular in Muslim majority society (1). Owing to that unpopularity, Bir Pletok can only be found in specific areas around Jakarta.

Bir Pletok experienced brand crisis in the last decade due to its packaging was monotone and unattractive. Bir Pletok's packaging was mainly dark and gloomy color. The young consumers tend to give negative reaction to Bir Pletok's packaging. The icon that being used in Bir Pletok's commonly were "Abang Betawi"; a male icon of Betawi. It reduced acceptance rate among female consumers (2).

Ice cream products had gain a high popularity throughout the world, especially during summer (3). For that reason, many research conducted to promote new innovations. Incorporation of prebiotic in ice cream showed to had higher melting point with higher apparent viscosity and particle size. Ice cream prebiotic incorporated showed less acceptance compared to conventional ice cream (4). Substitution of synthetic colorant with beta-carotene micro particle was conducted to give healthier food option. Ice cream incorporated with solid lipid encapsulated beta-carotene showed a better appearance and intense color compared to the control. Respondents also prefer ice cream with betacarotene compared to ice cream using synthetic/artificial colorant (5). Complemented ice 
cream for cancer patient was formulated in four flavor each consisted whey protein isolate, polydextrose, and deodorized olive oil. The acceptability of the formulated ice cream was high (above 75\%) with promising therapeutic possibility to be part of diet for cancer patient (6). Considering the popularity and potential of ice cream, ice cream expected to be able to be used to increase unpopular culinary heritage such as Bir Pletok.

\section{Materials and Methods}

The materials to produce Bir Pletok were $5 \mathrm{~L}$ mineral water with market name "Aqua"; 1 kg sugar with market name "Gulaku"; 250 g ginger "jahe emprit" variety; 20 pcs of cloves; $7 \mathrm{~g}$ lemon leaves; $10 \mathrm{~g}$ cinnamons; $12 \mathrm{~g}$ nutmeg; $70 \mathrm{~g}$ sappanwood; 50 pcs of cardamon; and $150 \mathrm{~g}$ of lemongrass. All materials were available in local market.

To make Bir Pletok, all ingredients were minced, then heated in the mineral water. Sugar and sappanwood were added lastly. The mixture was heated to its boiling point. The treatment stopped after mixture color turn to dark red. The mixture filtered and the residual was separated and disposed. Bir Pletok was ready to be used as an ice cream.

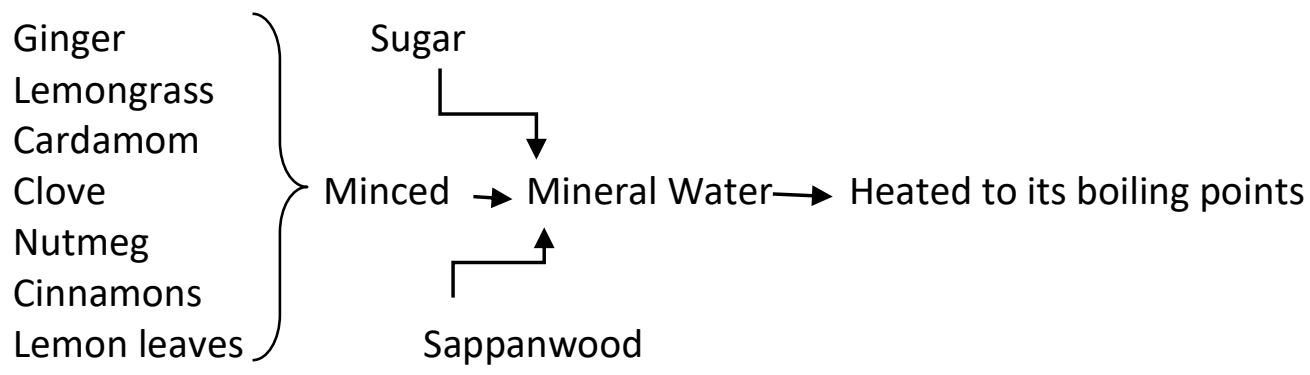

\section{Figure 1. Bir Pletok Production Chart Flow}

Materials to create ice cream were Bir Pletok itself, milk, sugar, egg, salt, and vanilla. $5 \mathrm{~kg}$ sugar; $30 \mathrm{~L}$ of UHT milk; $10 \mathrm{~L}$ of Bir Pletok; $5 \mathrm{~kg}$ of eggs; 5 spoons of vanilla; and a pinch of salt, procured from market, was used to create Bir Pletok Ice Cream. Egg yolk was separated and mixed with sugar using mixer. In separated bowl, white egg added with a pinch of salt and 5 spoons of vanilla was also mixed. After two mixture mixed properly, both egg yolk-sugar and white egg-salt-vanilla mixture was mixed together. Milk and Bir Pletok then being added to the mixture. Using mixer, the mixture was mixed thoroughly until properly blended. Mixture then being heated until viscous texture achieved. After that, the mixture being cooled and freeze inside freezer. 


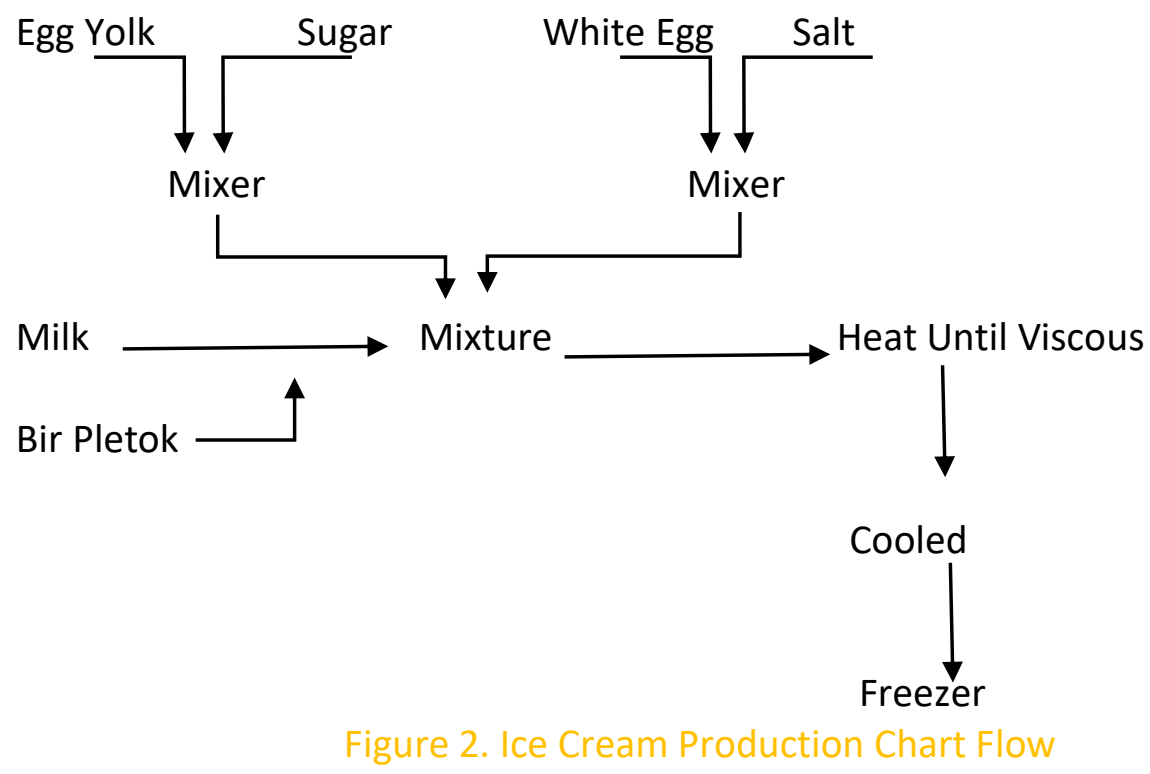

Ice cream descriptive attributes observed with descriptive qualitative method. The ice cream then exposed to sensory test. 30 untrained panelists with age ranged from 18-19 years old was chosen. The untrained panelist was subjected triangle test. Materials for triangle test were Caffeine produced by "tiga ikat" company, ascorbic acid $1000 \mathrm{mg}$ produced by "Kalbe", and sugar to replace glucose. The panelist was subjected to 3 sets of triangle test with three varieties of each tastant (caffeine, ascorbic acid, and sugar) those were $100 \mathrm{mg} / 200 \mathrm{ml} ; 75 \mathrm{mg} / 200 \mathrm{ml}$; and $50 \mathrm{mg} / 200 \mathrm{ml}$. 15 panelists with highest sensitivity to differ taste was chosen based on this test. Furthermore, the 15 panelists were trained and subjected to sensory test using hedonic test 7 scales methods. The scores representative for hedonic test were shown in table 1.

\begin{tabular}{|c|c|}
\hline Levels & Description \\
\hline 1 & Dislike very much \\
\hline 2 & Dislike \\
\hline 3 & Dislike slightly \\
\hline 4 & Neither like nor dislike \\
\hline 5 & Like slightly \\
\hline 6 & Like \\
\hline 7 & Like very much \\
\hline
\end{tabular}

Collected data were analyzed using Microsoft Excel. Data were analyzed using descriptive method. Panelists were trained to differ sweet, bitter, acid, and salty taste for 40 hours (highly trained panelist). 


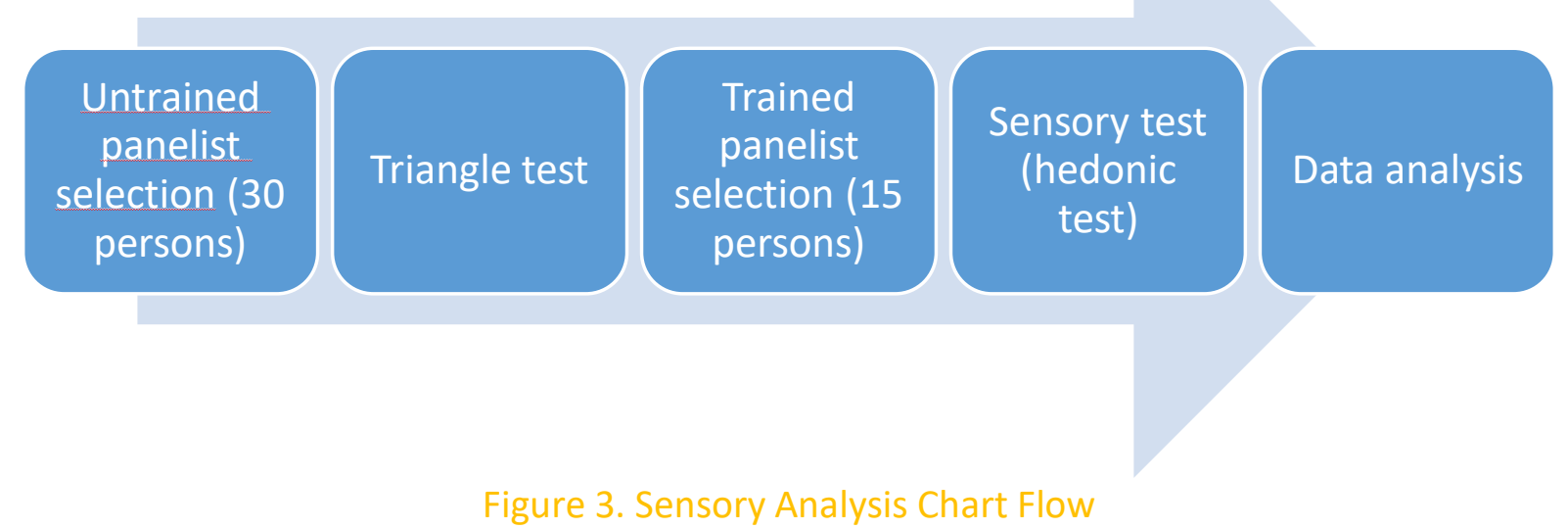

\section{Results and Discussion}

In this research, panellist that being chosen were panellist with ages ranged from 1819 years old. Young generation was very important for product development. In Polish, young consumers had higher impact especially to innovation in food. They also more open to new product, that's why understanding young consumers had very good impact in companies operating on or in planning to enter the Polish food market (7). In India a research to know the acceptance level of young consumers on GMF (Genetically Modified Food) was conducted to analyse the potential of GMF market in India. It was found that $41 \%$ of respondents willing to buy GMF. Female respondents had lesser acceptance to GMF compared to male respondents (8). Young respondents proved to preferred mainly hedonistic value in food compared to rational approach, that's why hedonic test judged as the most suitable method to approach the acceptability of food in young respondents (9). The result of triangle test was shown below.

\begin{tabular}{|c|c|c|c|c|c|c|}
\hline \multirow[t]{2}{*}{ No } & \multirow{2}{*}{$\begin{array}{l}\text { Tastant concentration } \\
\qquad(\mathrm{w} / \mathrm{v})\end{array}$} & \multicolumn{3}{|c|}{$\begin{array}{l}\text { Number of panelist who can } \\
\text { differentiate taste }\end{array}$} & \multirow{2}{*}{$\begin{array}{c}\text { Number } \\
\text { of } \\
\text { Sample } \\
\text { (N) }\end{array}$} & \multirow{2}{*}{$\begin{array}{c}\text { Average } \\
\text { / Mean } \\
(\%)\end{array}$} \\
\hline & & Set $A$ & Set B & Set C & & \\
\hline 1 & $100 / 200 \mathrm{mg} / \mathrm{ml}$ & 10 & 8 & 8 & 30 & 93.33 \\
\hline 2 & $75 / 200 \mathrm{mg} / \mathrm{ml}$ & 7 & 5 & 5 & 30 & 56.67 \\
\hline 3 & $50 / 200 \mathrm{mg} / \mathrm{ml}$ & 5 & 5 & 5 & 30 & 50.00 \\
\hline
\end{tabular}

In this research, it was found that most of the panellists were able to differ taste properly with tastant concentration $100 / 200 \mathrm{mg} / \mathrm{ml}$. 28 of 30 panellists could differ the taste properly. Reducing the concentration to $75 / 200 \mathrm{mg} / \mathrm{ml}$ found to decrease the ability of panellists to differentiate the taste. 17 out of 30 panellists were able to differ the taste properly. In tastant concentration $50 / 200 \mathrm{mg} / \mathrm{ml}$ only 15 out of 30 panellists were able to differ the taste properly. The ability to differ taste was called taste sensitivity. Concentration of the tastant and the odour affect the sensitivity to differ taste (10). However, the 
sensitivity also associated with food consumption behaviour. That's why it's very important to standardized the panellists used in sensory evaluation (11). Triangle test was an old method but it was very effective for selecting panellist and monitoring their performance to discriminate taste (12). Ideally triangle test can be applied to 20-40 panellists. But at least 12 panellists can be used in triangle test in condition the test was conducted with large difference and easy to identified (13).

From the formulation of Bir Pletok ice cream with 3:1 of milk: Bir Pletok, Bir Pletok ice cream had characteristic like below,

\begin{tabular}{|c|c|c|c|c|c|}
\hline \multicolumn{2}{|c|}{ Formulation } & \multicolumn{4}{|c|}{ Descriptive Attributes of Ice Cream } \\
\hline Ratio & Combination & Colour & Texture & $\begin{array}{c}\text { Flowing } \\
\text { Characteristic }\end{array}$ & Moisture \\
\hline $3: 1$ & $\begin{array}{l}\text { Milk: Bir } \\
\text { Pletok }\end{array}$ & Brownish & Firm & Stiff & Semi-moist \\
\hline
\end{tabular}

Bir Pletok Ice Cream made with 3:1 of milk: Bir Pletok shown brownish colour. Originally, Bir Pletok has reddish colour. The formulation found to eliminate the original colour of Bir Pletok. The ice cream found to have firm texture and stiff characteristic. The ice cream also found to have semi-moist moisture characteristic.

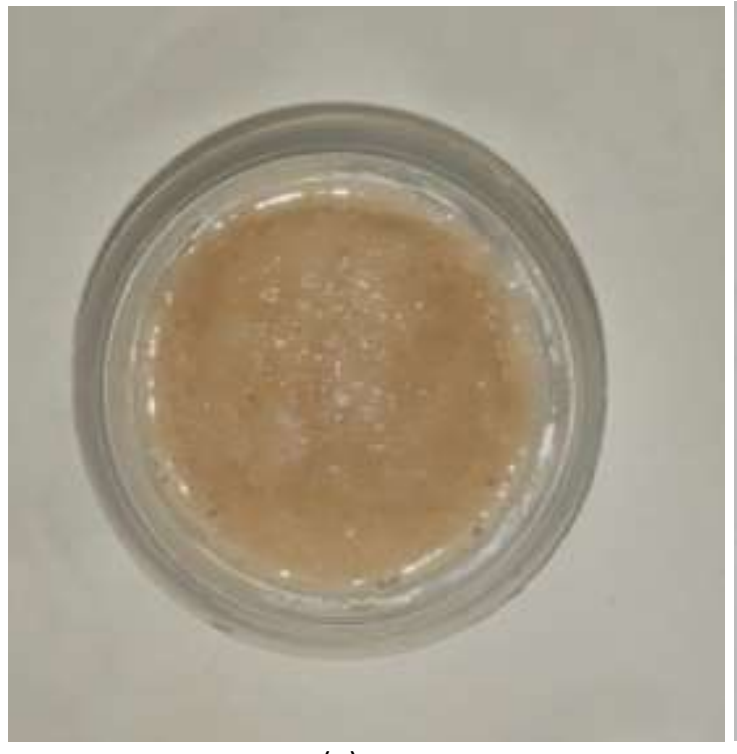

(a)

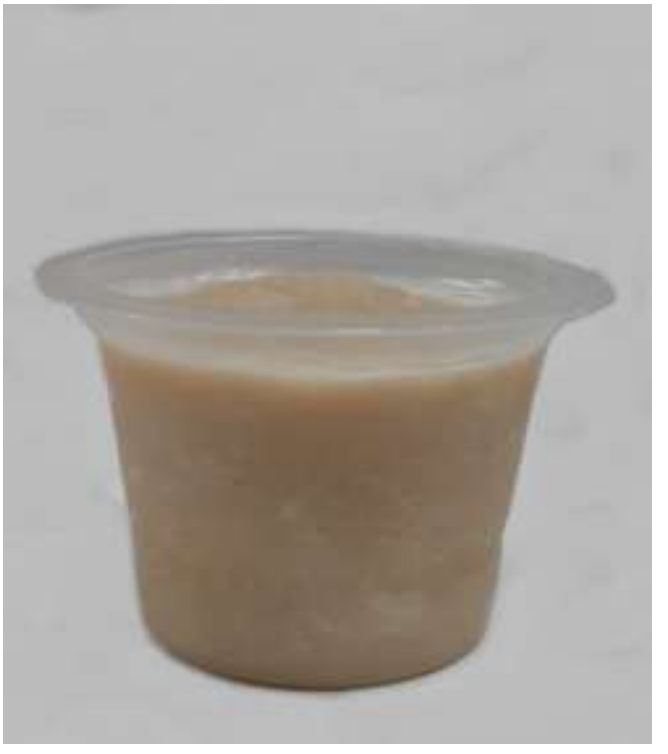

(b)

Figure 4. (a) Appearance of Bir Pletok Ice Cream from Above; (b) Side View of Bir Pletok Ice Cream.

Colour is one of the most important thing affecting food acceptability. In this research, colouring agent that being used was sappanwood as natural colouring agent. However, the colour of sappanwood as natural dye was not retained in food processing chain so that the ice cream lost the identic colour given by Bir Pletok. Mixing milk proved to affect the stability of natural dye. Natural dyes also known as bio-colour, usually react with milk resulting browning reaction. That's why bio-colour need special treatment when being used in dairy product (14). Till 2014 there only three natural dyes that can retain it colours in ice cream industry, that were Dactylopius coccus, Turmeric (Curcuma longa), and Camellia tea (Camellia thea) (15). 
Bir Pletok ice cream found to have firm texture and stiff flowing characteristic. Adding a component to ice cream can change the texture and flowing characteristic of ice cream. Texture and flowing characteristic was factors affecting ice cream viscosity. There was no exact standard for ice cream viscosity since difference consumer might desire different ideal standard for viscosity. Adding rice brand proved to increase the firmness and stiffness characteristic of ice cream (16). Firmness and stiffness of the ice cream also affected by fat content of the ice cream. The higher fat content in ice cream the stiffer and firmer the ice cream(17).

Bir Pletok ice cream found to have semi-moist moisture. Moisture affecting mouthfeel of ice cream. Standard moisture/solid of ice cream was 39.13. The higher the moisture the grittier the mouthfeel of ice cream (18). Fat content affect the moisture of the ice cream(19).

The result of sensory evaluation of Bir Pletok ice cream was shown on table 4.

\begin{tabular}{llllllllll} 
Table 4. Sensory & Characteristic of Bir Pletok Ice Cream Formulation 3: \\
\hline \multicolumn{1}{c}{ Parameters } & \multicolumn{7}{c}{$\begin{array}{c}\text { Number of Henic Scores Given } \\
\text { by Panellists }\end{array}$} & $\begin{array}{c}\text { Total Number of } \\
\text { Panellists }\end{array}$ \\
& 1 & 2 & 3 & 4 & 5 & 6 & 7 & \\
\hline Taste & 0 & 0 & 0 & 2 & 7 & 3 & 3 & 15 \\
Aroma & 0 & 0 & 2 & 5 & 5 & 2 & 1 & 15 \\
Colour & 0 & 1 & 4 & 6 & 2 & 1 & 1 & 15 \\
Mouth feel & 0 & 0 & 0 & 3 & 4 & 5 & 3 & 15 \\
After taste & 0 & 0 & 0 & 6 & 4 & 3 & 2 & 15 \\
\hline
\end{tabular}

In terms of taste, only 2 panellists gave 4 scores (neutral). Most of panellists slightly like the taste of Bir Pletok ice cream (7 panellists). The number of panellists who like (scores 6) and very much like (scores 7) the taste of Bir Pletok ice cream were 3 panellists for both scores. 2 panellists slightly didn't like the aroma of the formulated ice cream. 5 panellists gave neutral and slightly like responds, while 2 of the panellists slightly like the aroma. Only 1 panellist like the aroma very much.

For the colour of the formulated ice cream, 1 panellist didn't like the colour. 4 panellists slightly didn't like the colour, while 6 of it gave neutral responds (didn't like nor dislike). 2 of the panellists slightly like the colour, while panellists who liked and liked the colour very much was 1 for each responds. In term of mouthfeel, 3 panellists gave neutral responds, 4 panellists slightly liked it, 5 panellists liked it, while 3 panellists liked it very much. In term of after taste, 6 panellists gave neutral responds, 4 panellists slightly liked it, 3 panellists liked it, while 2 panellists liked it very much. To better analyse the responds of panellists, the responds was scored. The result of the scores were below.

\begin{tabular}{clcc}
\multicolumn{3}{c}{ Table 5. Hedonic Scores of Bir Pletok lce Cream Formulation 3:1 } \\
\hline \multirow{2}{*}{ No } & Sensory Characteristic & Mean Scores & Percentage \\
\hline 1 & Taste & 5.47 & $78.14 \%$ \\
2 & Aroma & 4.67 & $66.71 \%$ \\
3 & Colour & 4.07 & $58.14 \%$ \\
4 & Mouth feel & 5.53 & $79.00 \%$ \\
5 & After taste & 5.07 & $72.43 \%$ \\
& Overall acceptability & 4.96 & $70.86 \%$ \\
\hline
\end{tabular}


In this research, formulated ice cream had hedonic score 5.47 out of 7 for taste, 4.67 out of 7 for aroma, 4.07 out of 7 for colour, 5.53 out of 7 for mouthfeel, and 5.07 out of 7 for aftertaste. The hedonic score standard for acceptability of dairy product should be at least $75 \%$. The taste that should be avoided for dairy product was cowy, bitter, malty, musty, rancid, salty, or sour (20). The formulated ice cream had $78.14 \%$ percentage hedonic score for taste. The highest score for hedonic test was mouthfeel (79.00\%). That's mean, the taste and mouthfeel already suitable for commercial release. Unfortunately, the ice cream still need improvement in term of aftertaste, aroma and colour. Hedonic score for after taste was $72.43 \%$. Aroma gave $66.71 \%$ hedonic score. Lowest hedonic score was found in colour (58.14\%). These results were in accordance with previous researches. Ice cream enriched with doum syrup and pomegranate peel also found to have high scores in flavour (taste and aroma). But they had low scores in colour.

Using pomegranate peel as natural dye was not a good option for ice cream since the dye found to be deteriorated in ice cream production process (21). Adding natural food dye in dairy product ideally infused in last step of the production procedure. Using spray-dried microalgae as natural dye found effective when given after ice cream mixture being mixed well. Adding microalgae in mixture found gave less acceptance compared to infusing microalgae in the last step of production process. Adding too much microalgae as natural dye might affect the taste of the ice cream (22). A research studying aroma perception on saffron ice cream found that fat content affecting the aroma of the ice cream. The lower the fat content, the stronger and higher the perception of ice cream aroma (23). Formulated Bir Pletok ice cream had low hedonic scale for aroma (66.71\%). In future, replacing milk and reducing egg yolk in formulation might solve the low hedonic score for aroma of formulated ice cream. Mouthfeel was affected by sugar content, fat content and fibre content of ice cream. Sugar and fat found to affect the crystallisation of water molecule in ice cream. Fibre content gave gritty sensation in mouth. Agave fructans found can be used as fat and sugar substitute for ideal mouthfeel (24). However, in this research, mouthfeel of formulated ice cream was already high (79\%). A residual sweet taste found to be the most desired aftertaste in ice cream. Adding vanilla, sucralose, and sorbitol found increased the aftertaste acceptance of traditional vanilla ice cream (25). In this research formulated Bir Pletok ice cream had $72.43 \%$ score for mouthfeel. Increasing the number of vanilla that being used may increase the mouthfeel score in the future.

\section{Conclusions}

Bir Pletok ice cream with formulation 3:1 milk: Bir Pletok found to have medium overall acceptance (4.96). Highest hedonic score found in the mouthfeel of formulated ice cream (5.53), followed by the taste (5.47), and aftertaste (5.07). Lowest score found in colour (4.07), followed by aroma (4.67). Bir Pletok ice cream still need further improvement especially in colour and aroma.

\section{Acknowledgements}

Writers would love to thank you to LP3M Politeknik Negeri Media Kreative (PoliMedia) for the support in conducting this research. We also want to thank you to Department of Art Culinary PoliMedia to allow us to conduct the research in their department. 


\section{Author Contributions}

For this research, Dimas Bayu Pinandoyo responsible in experiments design and coordinate all the research process. Asriadi Masnar contribute in data analysist and article correction. Ratih Titik Haryati worked as field coordinator and formulator for the ice cream.

\section{References}

1. Wicaksono E, Tohir M. Perancangan Identitas Visual Dan Media Promosi Bir Pletok. eProceedings Art Des. 2018;5(3).

2. Haholongan W, Jayadi I. Perancangan desain kemasan sebagai media untuk menarik minat beli konsumen bir pletok (setu babakan). J Sist Inf. 2019;1(1):27-44.

3. Palka A, Newerli-Guz J, Furmaga D. Quality evaluation of take home vanilla ice cream. Zesz Nauk Akad Morskiej w Gdyni. 2016;

4. Aboulfazli F, Baba AS, Misran M. The rheology and physical properties of fermented probiotic ice creams made with dairy alternatives. Int J Food Eng. 2015;11(4):493504.

5. LIMA JG de, Brito-Oliveira TC, PINHO SC de. Characterization and evaluation of sensory acceptability of ice creams incorporated with beta-carotene encapsulated in solid lipid microparticles. Food Sci Technol. 2016;36(4):664-71.

6. Vieira FGK, De Salles RK, Mannes P, Kami AA, Búrigo T, Geraldo APG, et al. Development and acceptance of an ice cream as food alternative for cancer patients. J Culin Sci Technol. 2020;18(2):89-97.

7. Radzyminska M, Jakubowska D. The conceptualization of novel organic food products: a case study of Polish young consumers. Br Food J. 2019;

8. Kajale DB, Becker TC. Factors influencing young consumers' acceptance of genetically modified food in India. J Food Prod Mark. 2015;21(5):461-81.

9. Bubel D. Marketing aspect of young consumer behaviour in food industry management. Zesz Nauk Szk Głównej Gospod Wiej Ekon i Organ Gospod Żywnościowej. 2015;(112).

10. Puputti $S$, Aisala $H$, Hoppu U, Sandell M. Factors explaining individual differences in taste sensitivity and taste modality recognition among Finnish adults. J Sens Stud. 2019;34(4):e12506.

11. Puputti S, Hoppu U, Sandell M. Taste sensitivity is associated with food consumption behavior but not with recalled pleasantness. Foods. 2019;8(10):444.

12. Sharif M, Butt M, Sharif H, Nasir M. Sensory Evaluation and Consumer Acceptability. In 2017. p. 362-86.

13. Meyners M, Castura JC. Randomization of CATA attributes: Should attribute lists be allocated to assessors or to samples? Food Qual Prefer. 2016;48:210-5.

14. Meghwal M. Benefits of food colours and safety in usage. Ingredients South Asia. 2015 Dec 1;1:22-4.

15. Chaitanya Lakshmi G. Food coloring: the natural way. Res J Chem Sci. 2014;2231(8):606X.

16. Kurniawati T. Rice Bran Ice Cream Characteristics on Various Proportions of Rice Bran Flour with Skimmed Milk and Kinds of Stabilizer. J Trop Food Agroindustrial Technol. 2020;1(01):17-23.

17. Adapa S, Dingeldein H, Schmidt KA, Herald TJ. Rheological properties of ice cream 
mixes and frozen ice creams containing fat and fat replacers. J Dairy Sci. 2000;83(10):2224-9.

18. Syed QA, Anwar S, Shukat R, Zahoor T. Effects of different ingredients on texture of ice cream. J Nutr Heal Food Eng. 2018;8(6):422-35.

19. Rolon ML, Bakke AJ, Coupland JN, Hayes JE, Roberts RF. Effect of fat content on the physical properties and consumer acceptability of vanilla ice cream. J Dairy Sci. 2017;100(7):5217-27.

20. Schiano AN, Harwood WS, Drake MA. A 100-year review: Sensory analysis of milk. J Dairy Sci. 2017;100(12):9966-86.

21. Ismail HA, Hameed AM, Refaey MM, Sayqal A, Aly AA. Rheological, physio-chemical and organoleptic characteristics of ice cream enriched with Doum syrup and pomegranate peel. Arab J Chem [Internet]. 2020;13(10):7346-56. Available from: https://www.sciencedirect.com/science/article/pii/S1878535220302926

22. Durmaz Y, Kilicli M, Toker OS, Konar N, Palabiyik I, Tamtürk F. Using spray-dried microalgae in ice cream formulation as a natural colorant: Effect on physicochemical and functional properties. Algal Res. 2020;47:101811.

23. Feyzi S, Varidi M, Housaindokht MR, Es' haghi Z, Romano R, Piombino $P$, et al. A study on aroma release and perception of saffron ice cream using in-vitro and in-vivo approaches. Innov Food Sci Emerg Technol. 2020;65:102455.

24. Jardines AP, Arjona-Román JL, Severiano-Pérez $P$, Totosaus-Sánchez A, Fiszman $S$, Escalona-Buendía HB. Agave fructans as fat and sugar replacers in ice cream: Sensory, thermal and texture properties. Food Hydrocoll. 2020;108:106032.

25. Cadena RS, Bolini HMA. Time-intensity analysis and acceptance test for traditional and light vanilla ice cream. Food Res Int. 2011;44(3):677-83. 